\title{
INTERSPECIFIC COMPETITION BETWEEN NATIVE AND EXOTIC FRUIT FLY PARASITOIDSIN MIXED ORCHARDS IN MACEIO, ALAGOAS, BRAZIL ${ }^{1}$
}

\author{
JAKELINE MARIA DOS SANTOS ${ }^{2 *}$, SÔNIA MARIA FORTI BROGLIO² ${ }^{2}$ JÚLIO MARCOS MELGES WALDER $^{3}$, \\ DJISON SILVESTRE DOS SANTOS ${ }^{2}$, THIAGO RAMOS SILVA ${ }^{2}$
}

\begin{abstract}
The objective of this work was to assess the effects of the release and establishment of the exotic parasitoid Diachasmimorpha longicaudata (Ashmead, 1905) (Hymenoptera: Braconidae) and its interspecific competitive relationship with native fruit fly parasitoids in organic and conventional orchards in Maceio, State of Alagoas, Brazil. The exotic parasitoids were reared in the Radio-Entomology Laboratory of the Center for Nuclear Energy in Agriculture, University of São Paulo, Piracicaba, São Paulo, and released (112,350 individuals between five and eight days old) in orchards from June 8 to July12, 2013.Fruit samples were collected randomly every week during one year to assess the D. longicaudata recaptured from plants and fallen fruits on the ground, which were taken to the Entomology Laboratory of the CECA-UFAL, classified and individually placed in plastic containers, containing a layer of $1 \mathrm{~cm}$ of sand for pupation of the host larvae. The pupae, obtained after 10 days, were placed in Petri dishes with a layer of sand until the emergence of adults, which were then kept in plastic microtubes, containing ethanol $70 \%$. The release of exotic parasitoids did not displace native species. The same species were found before and after the release in both cultures: Doryctobracon areolatus, Asobara anastrephae, Utetes anastrephae and Opius bellus (Braconidae), Aganaspis pelleranoi (Figitidae) and individuals of the Pteromalidae family. One year after the last release, 44 individuals of the exotic parasitoid were found, showing its establishment in the studied areas.
\end{abstract}

Keywords: Biological control. Diachasmimorpha longicaudata. Tephritidae.

\section{COMPETIÇÃO INTERESPECÍFICA ENTRE PARASITOIDES NATIVOS E EXÓTICO DE MOSCAS-DAS-FRUTAS EM POMARES DIVERSIFICADOS EM MACEIÓ-AL}

RESUMO - O presente trabalho objetivou conhecer os efeitos da liberação, do estabelecimento e das relações de competitividade interespecífica entre o parasitoide exótico Diachasmimorpha longicaudata (Ashmead, 1905) (Hymenoptera: Braconidae) e as espécies de parasitoides nativos de moscas-das-frutas em pomar orgânico e convencional no município de Maceió, Alagoas. A criação do parasitoide exótico foi realizada no Laboratório de Radioentomologia do Centro de Energia Nuclear na Agricultura da Universidade de São Paulo (CENA/USP), em Piracicaba-SP. Foram liberados 112.350 indivíduos entre cinco e oito dias de idade, no período de 08 de junho a 12 de julho de 2013. Foram realizadas coletas de frutos semanalmente durante um ano, de forma aleatória, para avaliar a recaptura de D. longicaudata em plantas e em frutos caídos no solo, sendo estes encaminhados para o Laboratório de Entomologia do CECA-UFAL, onde os mesmos passaram por triagem e individualização em recipientes plásticos contendo uma camada de $1 \mathrm{~cm}$ de areia para pupação das larvas do hospedeiro. Após dez dias, os pupários obtidos foram acondicionados em placas de Petri com uma camada de areia até a emergência dos adultos, sendo estes conservados em microtubos plásticos contendo álcool 70\%. A liberação do parasitoide exótico não deslocou as espécies nativas, sendo obtidas as mesmas espécies antes e após a liberação em ambos os cultivos: os braconídeos Doryctobracon areolatus; Asobara anastrephae; Utetes anastrephae e Opius bellus; o figitídeo Aganaspis pelleranoi e exemplares da família Pteromalidae. Um ano após a última liberação, 44 exemplares do parasitoide exótico foram obtidos, mostrando estabelecimento nas áreas estudadas.

Palavras-chave: Controle biológico. Diachasmimorpha longicaudata. Tephritidae.

\footnotetext{
*Corresponding author

${ }^{1}$ Received for publication in 07/07/2015; accepted in 05/16/2016

Research supported by CAPES. Paper extracted from the doctoral thesis of the first author.

${ }^{2}$ Center of Agricultural Sciences, Universidade Federal de Alagoas, Rio Largo, AL, Brazil; jackbilu@hotmail.com, soniamfbroglio@gmail.com, djisonsilvestre@yahoo.com.br, thiagoramos.s@hotmail.com.

${ }^{3}$ Center of Nuclear Energy in Agriculture, Piracicaba, SP, Brazil; julio.walder@gmail.com.
} 


\section{INTRODUTION}

Parasitoids of the Braconidae family are the most important and used agents for biological control of fruit flies (PARANHOS; NASCIMENTO; WALDER, 2009). Diachasmimorpha longicaudata (ASHMEAD, 1905) is among the five most important species of this family that regulate fruit fly populations, parasitizing larvae of $2^{\text {nd }}$ and $3^{\text {rd }}$ instars (PURCELL et al, 1994).

Native parasitoids are commonly found controlling different Tephritidae species. Doryctobracon areolatus (Szépligeti, 1911) (Hymenoptera: Braconidae) stands out for its occurrence regarding fruit diversity and geographic distribution, and are found in various regions of Brazil. However, despite its more aggressiveness and efficiency in the field, the mass production of $D$. areolatus in artificial conditions was not yet successful (PARANHOS; NASCIMENTO; WALDER, 2009).

The exotic parasitoid D. longicaudata was introduced in Brazil in 1994 by the Embrapa Cassava and Fruticulture to improve the control of fruit flies in the country and, unlike $D$. areolatus, it is feasible to mass rearing (WALDER et al., 1995). Since its introduction in Brazil, studies have been conducted in several states to assess the interspecific competition with native parasitoids and its establishment in the regions where they were released, which showed no negative interference on species already established.

D. longicaudata individuals were released from July 1995 to August 1996 in Conceição do Almeida, Bahia, and recaptured up to April 1998. However, in the harvests of 2004 and 2005, during the fruit collections in this place, no $D$. longicaudata individuals were found. According to Carvalho, this result leads to the conclusion that the interspecific competition that the complex of species of native parasitoids imposed to the exotic Braconidae species by the oviposition sites, and the relatively small number of individuals D. longicaudata released, hindered their effective establishment in the area (CARVALHO, 2005).

D. longicaudata individuals were released from February 18 to August 25, 2003, in Jaiba and Nova Porteirinha, Minas Gerais, and no competition for the niche was found between Braconidae species, since the actions of the exotic parasitoids did not reduce the native populations (ALVARENGA et al., 2005). The authors suggested an extended period to evaluate the actual establishment of the exotic parasitoid. Collections were then carried out in three locations of Minas Gerais, including the previous two, from May1999 to April2001 and from June2002 to July2004, matching the periods of the year in which the individuals were released in those areas, and some D. longicaudata individuals were found
(ALVARENGA et al., 2009).

These results show that the $D$. longicaudata can establish in different regions without affecting the population of native parasitoids, even after certain periods without new releases. This behavior is noted in Brazil and in other countries. The establishment of $D$. longicaudata on $A$. fraterculus was proven 40 years after the first mass release in the province Misiones, Argentina, where about $1 \%$ of the quantity of parasitoids released was found (SCHLISERMAN; OVRUSKI; De COLL, 2003).

In this context, the objective of this work was to assess the interspecific competition between $D$. longicaudata and native fruit fly parasitoids and its establishment in organic and conventional orchards in Maceio, State of Alagoas, Brazil.

\section{MATERIAL AND METHODS}

\section{Preliminary survey on native parasitoid species.}

A survey on the fauna composition of native parasitoids was necessary to evaluate the effects of the introduction of the exotic parasitoid $D$. longicaudata in the native fauna of natural enemies of fruit flies. Thus, before the exotic parasitoid release, samples were taken from different fruit species in two areas located in Maceio, Alagoas (Table 1), one in Guaxuma, under organic system $\left(9^{\circ} 40^{\prime} \mathrm{S}, 35^{\circ} 42^{\prime} \mathrm{W}\right.$ and $110 \mathrm{~m}$ of altitude), and other in Serraria, under conventional system $\left(9.5^{\circ} 35^{\prime} \mathrm{S}\right.$, $35^{\circ} 42^{\prime} \mathrm{W}$ and $65 \mathrm{~m}$ of altitude), from March 2010 to February 2011 (SANTOS, 2012).

Fruit samples were collected weekly for 52 weeks, randomly chosen from different heights of the fruit trees, and from the ground (freshly fallen fruits). The number of fruits collected was different in each week, depending on the seasonal fruiting of each species. The samples were labeled (collection date, place and host fruit) and transported to the entomology laboratory of the Agricultural Science Center (CECA), Alagoas Federal University (UFAL). The fruits were classified, discarding those attacked by opportunistic organisms, counted, weighed and identified by species. The fruits had an external disinfection by immersion in a solution of water and sodium hypochlorite $1 \%$, preventing possible proliferation of fungi.The fruits were packed individually in plastic pots of sizes proportional to each fruit, with $1 \mathrm{~cm}$ layer of sand, which was previously sieved and sterilized in a forced air circulation oven at $80^{\circ} \mathrm{C}$ for 48 hours, to be used as substrate for pupation of the Tephritidae species. The pots were closed with covers that had small holes for aeration, labeled with the sample code and maintained at temperature of $26 \pm 1^{\circ} \mathrm{C}$ and air relative humidity of $70 \pm 10 \%$, which were measured with a digital thermo hygrometer. 
Table 1. Fruit trees sampled in organic and conventional crops in Maceio AL, before the release of Diachasmimorpha longicaudata. Survey conducted from March 2010 to February 2011.

\begin{tabular}{|c|c|c|c|c|}
\hline \multirow{2}{*}{$\begin{array}{l}\text { Family } \\
\quad \text { Species (common name) }\end{array}$} & \multicolumn{2}{|c|}{ Organic system } & \multicolumn{2}{|c|}{ Conventional system } \\
\hline & $\begin{array}{l}\text { Number of } \\
\text { fruits }\end{array}$ & $\begin{array}{l}\text { Weight } \\
(\mathrm{kg})\end{array}$ & $\begin{array}{l}\text { Number of } \\
\text { fruits }\end{array}$ & $\begin{array}{c}\text { Weight } \\
(\mathrm{kg})\end{array}$ \\
\hline \multicolumn{5}{|l|}{ Anacardiaceae } \\
\hline Anacardium occidentale L. (cashew) & 5 & 0.16 & - & - \\
\hline Mangifera indica L. (mango) & 272 & 127.07 & 79 & 30.46 \\
\hline Spondias dulcis Forst. (ambarella) & - & - & 28 & 2.21 \\
\hline Spondias lutea L. (yellow mombin) & 492 & 6.35 & 797 & 7.83 \\
\hline Spondias purpurea L. (red mombin) & 502 & 4.98 & 553 & 5.57 \\
\hline \multicolumn{5}{|l|}{ Annonaceae } \\
\hline Anonna muricata L. (soursop) & 5 & 4.3 & 43 & 51.8 \\
\hline $\begin{array}{l}\text { Euphorbiaceae } \\
\text { Manihot esculenta Crantz (cassava) }\end{array}$ & 431 & 0.8 & 303 & 0.6 \\
\hline $\begin{array}{l}\text { Malpighiaceae } \\
\text { Malpighia glaba L. (acerola) } \\
\text { Myrtaceae }\end{array}$ & 2,078 & 10.48 & 1,536 & 9.48 \\
\hline Eugenia uniflora L. (pitanga) & 3,486 & 10.10 & 2,389 & 6.8 \\
\hline Myrciaria trunciflora Berg. (jabuticaba) & - & - & 190 & 0.8 \\
\hline Psidium cattleianum Sabine (cherry guava) & 2,130 & 40.31 & 156 & 0.99 \\
\hline Psidium guajava L. (guava) & 665 & 50.05 & 797 & 108.39 \\
\hline Syzigium malaccence (L.) (malay apple) & 343 & 22.29 & - & - \\
\hline \multicolumn{5}{|l|}{ Oxalidaceae } \\
\hline $\begin{array}{l}\text { Averrhoa carambola L. (carambola) } \\
\text { Passifloraceae }\end{array}$ & 874 & 26.74 & 342 & 14.86 \\
\hline \multicolumn{5}{|l|}{ Passifloraceae } \\
\hline $\begin{array}{l}\text { Passiflora edulis flavicarpa Deg. (passion fruit) } \\
\text { Sapotaceae }\end{array}$ & 4 & 0.3 & - & - \\
\hline Manilkara zapota L. (sapodilla) & 124 & 7.7 & 52 & 6.1 \\
\hline Total & 8,764 & 287.89 & 5,113 & 174.9 \\
\hline
\end{tabular}

The fruits were removed from the containers after ten days and the pupae were found, counted, transferred to Petri dishes containing a $0.5 \mathrm{~cm}$ layer of sand and maintained in a room at the same temperature and humidity conditions in which the fruits were packed, until the emergence of adults. The parasitoids obtained were then stored in microtubes containing ethanol $70 \%$ for later identification.

\section{Rearing of the parasitoid Diachasmimorpha longicaudata in laboratory.}

The parasitoids were reared at the Radio-Entomology Laboratory of the Center for Nuclear Energy in Agriculture (CENA/USP), in Piracicaba SP, from an already domesticated population. The multiplication of parasitoids was conducted in Anastrepha fraterculus larvae. Adults of $A$. fraterculus were kept in cages made of acrylic, aluminum and voile fabric, with dimensions of $75 \times 30 \times 150 \mathrm{~cm}$, for oviposition. The colonies were kept in a $20 \mathrm{~m}^{2}$ room at temperature of $25 \pm 2^{\circ} \mathrm{C}$, relative humidity of $75 \pm 5 \%$ and 14 hours of photoperiod. A plastic container with $600 \mathrm{ml}$ of pupae diet for adults, consisting of sugar, wheat germ and hydrolyzed protein(3:1:1)was placed in each cage. The eggs were daily collected, measured and subjected to a 24-hour aeration to promote a greater uniformity and viability of larval hatching.

Subsequently, $2 \mathrm{~mL}$ of eggs were placed on a filter paper in a tray with $2 \mathrm{~kg}$ of the diet for subsequent feeding the larvae. The trays were covered with a dark fabric, to simulate the conditions inside the fruit, and placed in shelves at room temperature $\left(28\right.$ to $\left.30^{\circ} \mathrm{C}\right)$ and relative humidity $(85$ to $95 \%$ ). The diet and methodology used was based on Walder et al. (2014). Collections of larvae were performed when they were about to pupate, in the third larval stage, separating them from the diets by washing in water and filtering in a plastic sieve; $30 \%$ of these larvae was used to maintain the breeding of fruit flies and $70 \%$ were subjected to parasitism.

The larvae subjected to parasitism were packed in PVC dishes, with voile fabric at the bottom and placed in the cages $(50 \times 50 \times 30 \mathrm{~cm}$ dimensions) with adult parasitoids, thus exposing them to parasitism by 30 to 40 minutes, depending on the amount of parasitoids and larvae available. The larvae were then placed in trays with fine moist vermiculite as substrate and maintained at temperatures between 23 and $25^{\circ} \mathrm{C}$ and relative humidity of $75 \%$, in the absence of light.

The pupae obtained were measured, placed in plastic bags and packed in polystyrene boxes containing frozen packs (to maintain a low temperature) and a layer of polystyrene flakes (to avoid friction between pupae). Thus, this material was transported by air to Maceio AL, with five days before the emergence of parasitoids to avoid stress in the final development stages.

Quality control was carried out at each 
rearing stage of $A$. fraterculus with approximately 100 units taken at each development stage of the fly (egg, larva and pupa) to assess the feasibility of each of these phases and avoid reduction in the laboratory rearing. Pupae from larvae that were subjected to parasitism were also subjected to this quality control, to assess the pupal viability, parasitism and sex ratio of parasitoids.

\section{Release of the exotic parasitoids in the field.}

The volume of pupae sent to Maceio varied according to their availability in the laboratory. Five dispatches were carried out, with a total volume of $7.49 \mathrm{~L}$ of pupae. Regardless of the received amount, the pupae were equally divided and released in the two areas. They were packed in paper bags and placed into pots that had two lateral openings covered with voile fabric (to allow aeration during transport to the field) and two petri dishes with organic honey mixed with toilet paper to feed the adult parasitoids.

Five releases were performed from June 8 to July 12, 2013, totaling 112.35 million parasitoids, 56,175 females and 56,175 males, since the sex ratio found by the quality control of pupae samples was $1: 1$. The adults released were five to eight days old, since the D. longicaudata reaches higher parasitism efficiency in the period between the fifth and twelfth day of age (WALDER, 2002).

Containers with parasitoids were opened in the morning according to the wind direction and facing the plants, so that the insects had easy fly. The areas in which they were released had plants with fruits, favoring the parasitoid to meet the host. Paper bags containing pupae were hung on the plants for late emergence of parasitoids.

\section{Recapture of the Diachasmimorpha longicaudata specimens.}

The collection of fruits to recapture the $D$. longicaudata specimens started before the last release of parasitoids and continued for one year from July 2013 to June 2014. Samples were collected weekly, following the same methodology of the preliminary survey on the native parasitoid species.

\section{Interspecific competition.}

The evaluation of interspecific competition was performed after the introduction of $D$. longicaudata in the areas, using the percentage of parasitism and abundance of species of native parasitoids evaluated before and after the release of the exotic parasitoids. The parasitism index (PI) and abundance (A) of each native species were calculated by the formulas: Parasitism index = (number of parasitoids emerged / number of pupae obtained) $\mathrm{x}$ 100; and Abundance $=$ (number of parasitoid species / total number of parasitoids) $\mathrm{x}$ 100.

The abundance of each parasitoid species was calculated at each fruit collection in the organic and conventional systems before and after the release of the exotic parasitoids, considering each week a repetition. The data were converted to root of $\mathrm{x}$ and subjected to analysis of variance in a factorial 1:2:2 (parasitoid species: crop system: evaluation time), and the means were compared by Tukey test $(p<0.05)$. The results that had no significant interaction between the abundance of each species and the crop system and evaluation time were compared separately.

\section{Identification of parasitoids.}

The specific identification of parasitoids was based on the differences in the alar ribs, jaws position and in the propodeum morphology, following dichotomous keys described by Canal and Zucchi (2000). Confirmation of the species was carried out by Professor Valmir Antonio Costa from the Biological Institute of Campinas SP.

Control specimens are deposited in the entomology laboratory of the Agricultural Sciences Center, Alagoas Federal University.

\section{RESULTS AND DISCUSSION}

A total of 5,680 native parasitoids were found before the $D$. longicaudata release, 4,320 in the organic and 1,360 in the conventional system area. The wide difference in the number of parasitoids between areas was probably due to factors of the conventional system, such as the use of insecticides and other chemical inputs, as well as the reduced availability of fruits at certain times over the collections, by the lack of hand labor available for irrigation on the property.

Parasitoids were obtained from eight species of fruit trees in the organic crop and from seven species of fruit trees in the conventional crop. The same parasitoid species were found in both cultures (Table 2), with emphasis in the number of Eugenia uniflora, Psidium cattleianum and Spondias lutea found in the organic crop, and Eugenia uniflora, Spondias lutea and Spondias purpurea found in the conventional crop. These findings can be attributed to the greater availability of these fruit in the fields and to the morphological characteristics of these fruits, such as pulp size and thickness, which may favor the parasitism of native species.

The native parasitoid D. areolatus was predominant in both crops, with $67.5 \%$ in the organic 
and $71.0 \%$ in the conventional crop. This species is found in 18 states of Brazil and is reported as the predominant parasitoid species in other surveys carried out in the country (GONÇALVES et al., 2006; ZUCCHI, 2008; MARINHO et al., 2009; SANTOS, 2012; COSTA, 2012).

Table 2. Number of native parasitoids before the Diachasmimorpha longicaudata release in organic and conventional orchards with different fruit tree species in Maceio AL. Survey conducted from March 2010 to February 2011.

\begin{tabular}{|c|c|c|c|c|c|c|c|}
\hline \multicolumn{8}{|c|}{ Organic system } \\
\hline \multirow[b]{2}{*}{ Fruit species (common name) } & \multicolumn{7}{|c|}{ Parasitoids } \\
\hline & 1 & 2 & 3 & 4 & 5 & 6 & Total \\
\hline Averrhoa carambola L. (carambola) & 46 & 84 & 0 & 2 & 13 & 10 & 155 \\
\hline Eugenia uniflora L. (pitanga) & 370 & 31 & 119 & 307 & 4 & 1 & 832 \\
\hline Mangifera indica L. (mango) & 20 & 0 & 1 & 0 & 2 & 0 & 23 \\
\hline Psidium cattleianum Sabine (cherry guava) & 1,249 & 237 & 30 & 34 & 29 & 9 & 1,588 \\
\hline Psidium guajava L. (guava) & 184 & 1 & 2 & 0 & 19 & 1 & 207 \\
\hline Spondias lutea L. (yellow mombin) & 868 & 167 & 31 & 160 & 12 & 34 & 1,272 \\
\hline Spondias purpurea L. (red mombin) & 72 & 0 & 4 & 1 & 0 & 0 & 77 \\
\hline Syzigium malaccence (L.) (malay apple) & 106 & 0 & 42 & 18 & 0 & 0 & 166 \\
\hline Total & 2,915 & 520 & 229 & 522 & 79 & 55 & 4,320 \\
\hline \multicolumn{8}{|c|}{ Conventional system } \\
\hline & \multicolumn{7}{|c|}{ Parasitoids } \\
\hline Frutíferas & 1 & 2 & 3 & 4 & 5 & 6 & Total \\
\hline Averrhoa carambola L. (carambola) & 34 & 2 & 0 & 0 & 0 & 0 & 36 \\
\hline Eugenia uniflora L. (pitanga) & 65 & 3 & 14 & 95 & 0 & 0 & 177 \\
\hline Mangifera indica L. (mango) & 1 & 0 & 0 & 0 & 0 & 0 & 1 \\
\hline Psidium cattleianum Sabine (cherry guava) & 1 & 0 & 0 & 0 & 0 & 17 & 18 \\
\hline Psidium guajava L. (guava) & 13 & 0 & 0 & 0 & 4 & 0 & 17 \\
\hline Spondias lutea L. (yellow mombin) & 686 & 164 & 35 & 12 & 22 & 19 & 938 \\
\hline Spondias purpurea L. (red mombin) & 166 & 0 & 1 & 5 & 0 & 1 & 173 \\
\hline Total & 966 & 169 & 50 & 112 & 26 & 37 & 1,360 \\
\hline
\end{tabular}

1: Doryctobracon areolatus; 2: Asobara anastrephae; 3: Utetes anastrephae; 4: Opius bellus; 5: Aganaspis pelleranoi; 6 : Pteromalidae.

Sa et al. (2012) collected fruit flies in 21 plant species in three counties of Southern Bahia, but captured parasitoids (71 individuals) only in Malpighia glaba, Ziziphus joazeiro Mart. (Ramnacaeae), Spondias purpurea L. and Spondias tuberosa Arruda (Anacardiaceae), D. areolatus species $(88.7 \%)$ found in these four fruit tree species, and $A$. anastrephae $(11.3 \%)$ found only in $S$. tuberose and $S$. purpurea.

Silva et al (2007) evaluated six species of fruit in Ferreira Gomes, Amapá (AP), and found parasitoids D. areolatus $(50 \%)$, O. bellus (33.3\%), Opius sp. (12.7\%) and U. anastrephae (1\%) only in Spondias lutea. Silva and Silva (2007), evaluated ten fruit speciesin Itaubal do Piririm AP, and also found parasitoids only in Spondias lutea L., however, these were parasitoids from only two species: D. areolatus $(57.1 \%)$ and $A$. anastrephae (42.9\%).

Thomazini and Albuquerque (2009), conducted a survey in Bujari and Rio Branco, Acre, and found three Braconidae species, totaling 142 parasitoids, and the $O$. bellus was the most frequent species $(70.4 \%)$, found only in fruits of Spondias lutea, unlike what happened in other states.

After the release of $D$. longicaudata, during one year of collection to evaluate its recapture (July 2013 to June 2014), 16,861 fruit (393.4 kg) were collected in the organic crop area in 13 fruit species and7,719 parasitoids were found in nine fruit species. In the conventional crop area, 8,924 fruit
$(273.7 \mathrm{~kg})$ were collected in 13 fruit species and 2,293 parasitoids were found in nine fruit species.

The native parasitoids species collected before the $D$. longicaudata release remained in the two areas sampled and showed changes in their abundances, however, no diversity loss or displacement of any native species were found. The number of Pteromalidae individuals found in the conventional crop area was smaller than the number of D. longicaudata (Table 3), denoting a possible competition between D. longicaudata and Pteromalidae species in this area.

No significant interaction was found by the Tukey test at $5 \%$ probability between the abundance of species of native parasitoids in the crop systems (organic and conventional) and the evaluation time (before and after the release of D. longicaudata), indicating that that presence of $D$. longicaudata does not influence the abundance of native parasitoids. Thus, the abundance of these species was compared separately regarding the crop systems and evaluation time (Table 4).

The abundances of parasitoids $D$. areolatus and $O$. bellus were influenced by the crop system, with higher frequency of $D$. areolatus in the organic and $O$. bellus in the conventional crop. This result was probably due to the populations of host flies to these two species and the management adopted in these crops. The abundance of $D$. longicaudata was not affected by the crop system. 
Table 3. Number of parasitoids found after the release of Diachasmimorpha longicaudata in different fruit species of organic and conventional crops in Maceio, Alagoas, Brazil. Survey conducted from July 2013 to June 2014.

\begin{tabular}{|c|c|c|c|c|c|c|c|c|}
\hline \multicolumn{9}{|c|}{ Organic system } \\
\hline \multirow[b]{2}{*}{ Fruit species (common name) } & \multicolumn{8}{|c|}{ Parasitoids } \\
\hline & 1 & 2 & 3 & 4 & 5 & 6 & 7 & Total \\
\hline Averrhoa carambola L. (carambola) & 159 & 41 & 0 & 9 & 17 & 0 & 2 & 228 \\
\hline Eugenia uniflora L. (pitanga) & 328 & 3 & 23 & 448 & 2 & 3 & 3 & 810 \\
\hline Mangifera indica L. (mango) & 21 & 0 & 0 & 0 & 0 & 3 & 0 & 24 \\
\hline Manilkara zapota L. (sapodilla) & 49 & 0 & 0 & 1 & 2 & 0 & 0 & 52 \\
\hline Psidium cattleianum Sabine (cherry guava) & 1,510 & 377 & 33 & 209 & 39 & 14 & 25 & 2,207 \\
\hline Psidium guajava L. (guava) & 88 & 12 & 0 & 0 & 78 & 1 & 1 & 180 \\
\hline Spondias lutea L. (yellow mombin) & 2,650 & 480 & 249 & 312 & 11 & 7 & 33 & 3,742 \\
\hline Spondias purpurea L. (red mombin) & 217 & 0 & 13 & 31 & 0 & 1 & 0 & 262 \\
\hline Syzigium malaccence (L.) (malay apple) & 162 & 0 & 41 & 10 & 0 & 1 & 0 & 214 \\
\hline Total & 5,184 & 913 & 359 & 1,020 & 149 & 30 & 64 & 7,719 \\
\hline \multicolumn{9}{|c|}{ Conventional system } \\
\hline & \multicolumn{8}{|c|}{ Parasitoids } \\
\hline Fruit species (common name) & 1 & 2 & 3 & 4 & 5 & 6 & 7 & Total \\
\hline Averrhoa carambola L. (carambola) & 206 & 82 & 5 & 5 & 45 & 7 & 4 & 354 \\
\hline Eugenia uniflora L. (pitanga) & 36 & 0 & 14 & 216 & 0 & 0 & 1 & 267 \\
\hline Malpighia glaba L. (acerola) & 0 & 0 & 0 & 0 & 1 & 0 & 0 & 1 \\
\hline Mangifera indica L. (mango) & 20 & 4 & 1 & 0 & 3 & 0 & 0 & 28 \\
\hline Manilkara zapota L. (sapodilla) & 10 & 0 & 0 & 0 & 0 & 1 & 0 & 11 \\
\hline Psidium cattleianum Sabine (cherry guava) & 8 & 0 & 0 & 4 & 0 & 0 & 0 & 12 \\
\hline Psidium guajava L. (guava) & 79 & 0 & 0 & 2 & 4 & 0 & 6 & 91 \\
\hline Spondias lutea L. (yellow mombin) & 1,016 & 170 & 156 & 3 & 0 & 6 & 0 & 1,351 \\
\hline Spondias purpurea L. (red mombin) & 168 & 0 & 5 & 2 & 1 & 0 & 0 & 176 \\
\hline Total & 1,543 & 256 & 181 & 232 & 54 & 14 & 11 & 2,291 \\
\hline
\end{tabular}

1: Doryctobracon areolatus; 2: Asobara anastrephae; 3: Utetes anastrephae; 4: Opius bellus; 5: Aganaspis pelleranoi; 6: Diachasmimorpha longicaudata; 7: Pteromalidae.

Table 4. Average abundance (\%) of native species of parasitoids and Diachasmimorpha longicaudata in organic and conventional crops, before and after its release.

\begin{tabular}{lcc}
\hline & Crop systems & \\
\hline Species of parasitoids & Organic & Conventional \\
\hline Doryctobracon areolatus & $61.5 \mathrm{a}$ & $52.8 \mathrm{~b}$ \\
Asobara Anastrephae & $10.4 \mathrm{a}$ & $7.4 \mathrm{a}$ \\
Utetes anastrephae & $6.1 \mathrm{a}$ & $7.4 \mathrm{a}$ \\
Opius bellus & $17.8 \mathrm{a}$ & $26.4 \mathrm{~b}$ \\
Aganaspis pelleranoi & $2.8 \mathrm{a}$ & $3.7 \mathrm{a}$ \\
Pteromalidae & $1.2 \mathrm{a}$ & $2.2 \mathrm{a}$ \\
Diachasmimorpha longicaudata & $0.4 \mathrm{a}$ & $0.3 \mathrm{a}$ \\
\hline & Evaluation time & \\
\hline & Before & After \\
\hline Doryctobracon areolatus & $56.3 \mathrm{a}$ & $59.1 \mathrm{a}$ \\
Asobara Anastrephae & $9.1 \mathrm{a}$ & $9.1 \mathrm{a}$ \\
Utetes anastrephae & $7.5 \mathrm{a}$ & $5.8 \mathrm{a}$ \\
Opius bellus & $22.6 \mathrm{a}$ & $20.6 \mathrm{a}$ \\
Aganaspis pelleranoi & $2.0 \mathrm{a}$ & $4.3 \mathrm{a}$ \\
Pteromalidae & $2.6 \mathrm{a}$ & $0.8 \mathrm{a}$ \\
\hline
\end{tabular}

Means followed by the same letter in the line do not differ by Tukey test at $5 \%$ probability.

The abundances of parasitoids $D$. areolatus and $O$. bellus were influenced by the crop system, with higher frequency of $D$. areolatus in the organic and $O$. bellus in the conventional crop. This result was probably due to the populations of host flies to these two species and the management adopted in these crops. The abundance of $D$. longicaudata was not affected by the crop system.

The abundance of native species was not affected by the release of $D$. longicaudata. D. areolatus remained more abundant compared with other species in both crops and after the release of the exotic parasitoid. This result is similar to those found in other studies. Alvarenga et al (2005) evaluated two orchards in Minas Gerais and, although $D$. areolatus was the only native species found, it remained most frequent after the release of D. longicaudata. According to these authors, no competition for the niche was found between the Braconidae species, since the action of the exotic did not reduce the population of native parasitoids.

Carvalho (2005) evaluated releases of $D$. longicaudata in an area that had no use of pesticides in Bahia, and found that the native Braconidae $D$. 
areolatus remained the most frequent, occurring only a reduction of $18.1 \%$ after releasing the exotic parasitoid, probably due to interspecific competition for oviposition sites, according to this author. $\mathrm{He}$ also found an increase in the frequency of the native Braconidae species $A$. anastrephae (from 0.2 to $1.0 \%$ ), $U$. anastrephae (from 1.77 to $9 \%$ ) and $A$. pelleranoi (from 0.1 to $1.0 \%$ ).

A decrease in the frequency of $D$. longicaudata with the number of days after the release has been observed in some studies. Bomfim, Carvalho and Carvalho (2009) evaluated the frequency of parasitoids before and after 24 and 48 hours of release $D$. longicaudata in two locations in Bahia, and found lower frequency of the exotic parasitoid at 48 compared with 24 hours after its release. However, according to these authors, the native species $D$. areolatus was the most frequent before and after the release, thus, the release of the exotic species $D$. longicaudata had no negative effect on the occurrence of native parasitoids.

\section{Recapture and establishing of Diachasmimorpha longicaudata.}

From the 112,350 parasitoids Diachasmimorpha longicaudata released $(56,175$ in each crop), only $44(0.04 \%)$ were recaptured one year after the last release, 30 in the organic area in the fruits of $P$. cattleianum (14), S. lutea (7), $M$. indica (3), E. uniflora (3), P. guajava (1), S. purpurea (1) and $S$. malaccence (1); and 14 in the conventional area in fruits of $A$. carambola (7), $S$. lutea (6) and $M$. zapota (1). Although few individuals have been found after a year of release, this species bred and settled in these crops. Moreover, D. longicaudata may be found in forested areas close to these crops, parasitizing fly larvae in wild fruits. However, new releases are recommended to increase the biological control of native species, increasing the efficiency and population of this exotic parasitoid.

Alagoas is the third state, in the Northeast region, in which $D$. longicaudata was released. The states of Bahia, Pernambuco, Minas Gerais, São Paulo, Rio Grande do Sul and Amazonas first started releases of this species in Brazil, aiming its establishment (CARVALHO; NASCIMENTO, 2002).

The number of insects recaptured is variable and lower than the total D. longicaudata released in Brazilian regions, possibly due to the fact that this species has no ability to find its host as native species, which are already adapted to the regions.

Carvalho and Nascimento (2002) released 77,400 individuals in different orchards for 15 months in areas of the sub-middle São Francisco River, which covers the states of Pernambuco and Bahia, and only 151 D. longicaudata individuals were recaptured $(0.2 \%)$.
Carvalho (2005) released 42,963 parasitoids during 11 months (August 1995 to June 1996) with weekly releases, in Conceição do Almeida, Bahia, and recaptures from one to 18 months after the first release. He recaptured 258 individuals, approximately $0.6 \%$ of total releases, however, when recaptures were carried out to confirm the effective establishment of D. longicaudata during the 2004 and 2005 harvests were, no individuals of the parasitoid were found.

Alvarenga et al (2005) released a 68,900 parasitoids during seven months in Jaiba and Nova Porteirinha, North of Minas Gerais, and recaptured 37 D. longicaudata individuals, one week after the first release, with $24(0.03 \%)$ in Jaiba and 13 $(0.02 \%)$ in Nova Porteirinha.

In February and April 1999, 850,000 D. longicaudata were released in Oiapoque, Amapá, and only $66(0.008 \%)$ individuals were recaptured from May to July,1999, anddespite the introduction of this species in the state, no individual was recaptured in the several subsequent surveys conducted (CARVALHO; NASCIMENTO, 2002; MARINHO; SILVA; ZUCCHI, 2011).

The low number of $D$. longicaudata insects recaptured and its establishment in few regions of the world can be explained by various causes, such as climatic conditions, host and number of insects released. Researches in Brazil show that recaptures of $D$. longicaudata after mass or inoculative releases did not have the expected results.

D. longicaudata is a species of interest to control Tephritidae species, and the recapture of adults of this parasitoid after their release means that it can adapt and develop in field conditions in an area, expanding the control of fruit flies by native parasitoid species. Moreover, to prove its establishment, their recapture for longer periods after the release is needed, and most surveys does not exceed one year after the last release.

Results of researches conducted in different regions of Brazil show a small number of recaptured insects, thus denoting that, for our conditions, to perform successive inoculative releases of $D$. longicaudata would be appropriated, which would potentially increase the establishment chance, or instead, to direct researches to native species that have greater impact and efficiency in the field.

\section{CONCLUSIONS}

The exotic parasitoids did not displace the native parasitoids. The same species were obtained after the release of $D$. longicaudata in the organic and conventional crops.

The D. longicaudata was found in nine fruit trees and settled in the two crops during the study period, despite showing a possible competition with Pteromalidae species in the conventional system and 
only 44 specimens of $D$. longicaudata had been recaptured.

\section{ACKNOWLEDGEMENTS}

The authors thank the owners of the Paraiso Farm, Mr. George Lins da Cunha and the owner of the Aldeia Verde Farm, Mr. Ricardo Luiz Rocha Ramalho Cavalcante, who kindly provided the areas for this research and to the biologists Maria de Lourdes Zamboni Costa and Luis Anselmo Lopes by the support and dedication at the Radio-Entomology Laboratory of the Center for Nuclear Energy in Agriculture (CENA/USP) during multiplication of parasitoids.

\section{REFERENCES}

ALVARENGA, C. D. et al . Introdução e recuperação do parasitóide exótico Diachasmimorpha longicaudata (Ashmead) (Hymenoptera: Braconidae) em pomares comerciais de goiaba no norte de Minas Gerais. Neotropical Entomology, Londrina, v. 34, n. 1, p. 133-136, 2005.

ALVARENGA, C. D. et al. Moscas-das-frutas (Diptera: Tephritidae) e seus parasitoides em plantas hospedeiras de três municípios do norte do estado de Minas Gerais. Arquivos do Instituto Biológico, São Paulo, v. 76, n. 2, p. 195-204, 2009.

BOMFIM, Z. V.; CARVALHO, R. da S.; CARVALHO, C. A. L. de. Relações interespecíficas entre parasitoides nativos de moscas-das-frutas e o braconídeo exótico Diachasmimorpha longicaudata em frutos de 'umbu-cajá'. Ciência Rural, Santa Maria, v. 40, n. 1, p. 77-82, 2009.

CANAL, N. A.; ZUCCHI, R. A. Parasitoides Braconidae. In: MALAVASI, A.; ZUCCHI, R. A. (Eds.). Moscas-das-frutas de importância econômica no Brasil: conhecimento básico e aplicado. Ribeirão Preto: Holos, 2000. p. 119-126.

CARVALHO, R. da S. Avaliação das liberações inoculativas do parasitóide exótico Diachasmimorpha longicaudata (Ashmead) (Hymenoptera: Braconidae) em pomar diversificado em Conceição do Almeida, BA. Neotropical Entomology, Londrina, v. 34, n. 5, p. 799-805, 2005.

CARVALHO, R. da S.; NASCIMENTO, A. S. Criação e utilização de Diachasmimorpha longicaudata para controle biológico de moscas-das-frutas (Tephritidae). In.: PARRA, J. R. P. et al. (Eds.). Controle Biológico no Brasil: parasitoides e predadores. São Paulo: Manole, 2002. p. 165-179.

COSTA, S. S. Biodiversidade de moscas-das-frutas (Diptera: Tephritoidea) e seus parasitoides em diferentes microrregiões do estado de Alagoas. 2012. 117 f. Dissertação (Mestrado em Agronomia: Área de concentração em Proteção de Plantas) - Universidade Federal de Alagoas, Centro de Ciências Agrárias, Rio Largo, 2012.

GONÇALVES, G. B. et al. Occorrence of fruit flies (DIPTERA: TEPHRITIDAE) in the state of Alagoas, Brasil. Florida Entomologist, Lutz, v. 89, n. 1, p. 93 $-94,2006$

MARINHO, C. F. et al. Parasitóides (Hymenoptera: Braconidae) de moscas-das-frutas (Diptera: Tephritidae) no Estado de São Paulo: Plantas Associadas e Parasitismo. Neotropical Entomology, Londrina, v. 38, n. 3, p. 321-326, 2009.

MARINHO, C. F.; SILVA, R. A.; ZUCCHI, R. A. Chave de identificação de Braconidae (Alysiinae e Opiinae) parasitoides de larvas frugívoras na região Amazônica. In: SILVA, R. A.; LEMOS, W. P.; ZUCCHI, R. A. (Eds.). Moscas-das-frutas na Amazônia brasileira: diversidade, hospedeiros e inimigos naturais. Macapá: Embrapa Amapá, 2011. p. 91-101.

PARANHOS, B. A. J.; NASCIMENTO, A. S.; WALDER, J. M. M. Controle biológico de moscas-das-frutas. In: MALAVASI, A; VIRGÍNIO, J. (Eds.). Biologia, monitoramento e controle 5: curso internacional de capacitação em moscas-das-frutas. Juazeiro, BA. 2009. p. 29-31.

PURCELL, M. F. et al. Influence of guava ripening on parasitism of the oriental fruit-fly, Bactrocera dorsalis (Hendel) (Diptera: Tephritidae), by Diachasmimorpha longicaudata (Ashmead) (Hymenoptera: Braconidae) and other parasitoids. Biological Control, San Diego, v. 4, n. 1, p. 396-403, 1994.

SÁ, R. F. et al. Parasitismo natural em moscas-das-frutas (Diptera: Tephritidae) no semiárido do sudoeste da Bahia, Brasil. Revista Brasileira de Fruticultura, Jaboticabal, v. 34, n. 4, p. 1266-1269, 2012 .

SANTOS, J. M. dos. Levantamento populacional de moscas-das-frutas (Diptera: Tephritidae), seus parasitoides e hospedeiros em cultivo orgânico e convencional em Maceió, AL. 2012. $77 \mathrm{f}$. Dissertação (Mestrado em Agronomia: Área de concentração em Proteção de Plantas), Universidade Federal de Alagoas, Centro de Ciências Agrárias, 
Rio Largo, 2012.

SCHLISERMAN, P.; OVRUSKI, S. M.; de COLL, O. R. The establishment of Diachasmimorpha longicaudata (Hymenoptera: Braconidae) in Misiones, Northeastern Argentina. Florida Entomologist, Gainesville, v. 4, n. 86, p. 491-492, 2003.

SILVA, R. A. et al. Hospedeiros e parasitoides de Anastrepha spp. (Diptera: Tephritidae) em Itaubal do Piririm, Estado do Amapá. Ciência Rural, Santa Maria, v. 37, n. 2, p. 557-560, 2007.

SILVA, W. R.; SILVA, R. A. Levantamento de moscas-das-frutas e de seus parasitóides no município de Ferreira Gomes, Estado do Amapá. Ciência Rural, Santa Maria, v. 37, n. 1, p. 265-268, 2007.

THOMAZINI, M. J.; ALBUQUERQUE, E. S. Parasitoides (Hymenoptera: Braconidae) de Anastrepha Schiner (Diptera: Tephritidae) no estado do Acre. Acta Amazônica, Manaus, v. 39, n. 1, p. 245-248, 2009.

WALDER, J. M. M. Produção de moscas-das-frutas e seus inimigos naturais: associação de moscas estéreis e controle biológico. In: PARRA, J. R. P. et al. (Eds.). Controle Biológico no Brasil: parasitóides e predadores. São Paulo: Manole, 2002. v. 1, cap. 11 , p. 181-190.

WALDER, J. M. M. et al. Criação e liberação do parasitoide Diachasmimorpha longicaudata (Ashmead) (Hymenoptera: Braconidae) para controle de moscas-das-frutas no estado de São Paulo. Laranja, Cordeirópolis, v. 16, n. 1, p. 149-153, 1995.

WALDER, J. M. M. Large scale artificial rearing of Anastrepha sp.1 aff. fraterculus (Diptera: Tephritidae) in Brazil. Scientia Agricola, Piracicaba, v. 71, n. 4, p. 281-286, 2014.

WALDER, J. M. M.; COSTA, M. L. Z.; MASTRANGELO, T. A. Produção massal do parasitoide Diachasmimorpha longicaudata para o controle biológico de moscas-das-frutas. In: BUENO, V. H. P. (Ed.) Controle biológico de pragas: produção massal e controle de qualidade. Lavras: Editora da UFLA, 2009. p. 221-231.

ZUCCHI, R. A. Fruit flies in Brazil: Anastrepha species their host plants and parasitoids. 2008. Disponível em: <www.lea.esalq.usp.br/anastrepha/>. Acesso em: 08 de jun. 2015. 